\title{
The spirituality of St. John XXIII (Angelo Giuseppe Roncalli) and his ministry of teaching in the encyclical of his pontificate (1959-1963)
}

\section{SUMMARY}

Życie i posługa A. G. Roncallego jako prezbitera i biskupa ukazuje prawdę właściwą teologii duchowości chrześcijańskiej o jej absolutnie pneumatologicznym wymiarze. Stąd życie duchowe chrześcijanina określano jako życie w Duchu Świętym, a mówiąc o jego konstytutywności wskazywano na ciało, duszę i Ducha Świętego. Jednoczy On życie osobiste człowieka, z tym wszystkim, co je tworzy w ontyczną jedność. W przypadku osoby duchownej chodzi w tym wymiarze o jednoczenie tego kim się jest w porządku natury i łaski, z tym, co się głosi z jednoczesnym otwieraniem się na przenikanie życia i posługi Duchem Świętym. Nie czyni to w punkcie wyjścia z człowieka - prezbitera, biskupa świętego a raczej w doświadczeniu grzechu i słabości wprowadza na drogę nawrócenia i przemiany życia w kierunku ostatecznego zjednoczenia się z Bogiem w Jezusie Chrystusie. Stąd właśnie echo osobistego doświadczenia duchowego Roncallego w jego apostolskim posługiwaniu. Niniejsze studium jest próbą ukazania tej części nauczania św. Jana XXIII, która zawarta jest w encyklikach z odniesieniem jej do jego duchowości poznawanej w osobistych pismach.

Słowa klucze: Jan XXIII, duchowość ludowa, duchowość prosta, duchowość mistyczna. 
Teologia duchowości

The canonization process and canonization of Pope John XXIII (Angelo Giuseppe Roncalli) have given an opportunity to reach into his literary and find in it the source of his Christian experience and a spiritual inspiration to the ministry of the priest and bishop, above all, the successor of St. Peter.

The main source for this type of study are usually letters and notes consolidating inner experience. The spiritual legacy of literary by A. G. Roncalli in this regard is very rich. His Journal of a soul (Il Giornale dell'anima) has become very useful in the development of the spiritual life of many generations and was translated and published in Polish for the first time in 1965, written continuously since 1895 until the last days of his life (1963). Without a doubt, this is the primary source for Roncalli's description and interpretation of the Christian experience.

There is also another source, unfortunately, entirely unpublished, which record personal relationships and everyday life episodes that form Roncalli's path to holiness and have a particular impact on the figure of his spirituality and allowed to see him as the "Good Pope". It is a diary written by him (Diario intimo). Few of its parts have been placed in eyewitnesses of his life among others Bishop L. F. Capovilla, who had been the personal secretary of Roncalli for many years.

A third source for describing the spiritual experience of the Pope are his letters ${ }^{1}$ written to his family for over 60 years in which the Saint appears as a man of evangelical simplicity. Their narrative character allows to enter into a life of the seminarian, priest and bishop (the pope) as a human being unchangeable in his engaging way of life, who can enjoy the ordinary circumstances and in a direct way talk about the difficulties in the apostolic ministry and the weaknesses of a human nature.

These three extremely important sources for Christian spirituality helped researchers of Roncalli and his work to describe his spirituality as: folk (popolare), simple (semplice), uniform (unitarians) and mystical (mistica) $)^{2}$.

1 They were first published in Italian and has not been translated into Polish. Cf. Giovanni XXIII, Lettere ai famigliari, Roma 1968. Other editions of letters A. G. Roncalli: Questa Chiesa che tanto amo: lettere ai vescovi di Bergamo, Cinisello 2002; Lettere del pontificato, Cinisello 2008; Lettere dall'Oriente e altre inedite, Panzano in Chianti 2010; Il lupo, l'orso, l'agnello. Epistolario bulgaro con don K. Raev e mons. D. Theelen, Cinisello 2013; Lettere di fede e amicizia (1925-1963), Roma 2013.

2 Cf. L. F. Capovilla, La spiritualità di Giovanni XXIII e le Sue Radici, in http:// www.papagiovanni.com/sito/pensiero/articoli-e-studi.html [access date:17 November 2015]. 
Scratches of John XXIII spirituality, which he expressed in the aforementioned sources were reflected also in his Petrine ministry, so-called "solemn teaching" expressed in encyclicals.

A short because only a five-year pontificate (1958-1963) left eight encyclicals, which by definition will help preserve unity in the Church, faith and beliefs ${ }^{3}$, but they are also seeing the ecclesial matters, the answer to the Church posed by the contemporary world of questions and often express prophecy of the Petrine ministry which is somehow the result of a mystical experience of God, His inspiration. The study of these documents reveals in them the aforementioned features of John XXIII spirituality.

\section{Folk Spirituality}

The concept of folk spirituality may mistakenly be associated with a specific Christian folklore when in fact it is a spirituality rooted in the truth about man - the image and likeness of God and concern for men requested that their Christian vocation achieve by daily assimilation to God who has revealed himself in His Son Jesus Christ.

Basic concepts relating to a human being resounded in the first encyclical Ad Petri Cathedram (To the Chair of Peter) which was announced June 5, 1959. Showing the goals of his pontificate John XXIII pointed the source of true happiness of man, which seem to constitute a kind of "lived spirituality" a the Saint. The Pope divided His encyclical into four chapters: the truth; unity, harmony and peace; unity of the Church and paternal encouragement. It seems that the issues raised by Roncalli do not only relate to the foundations of Christian life, but also find support in his personal path to holiness.

The truth is inextricably linked with humility. It does not mean giving up what is characteristic of human nature but on the contrary it seeks to reveal deposited in man the gift of God and serve it in the environment. In this way God's plan for creation to the Creator is carried out. Thanks to this creature can unite with his Creator. The Saint wrote about it in the Journal of a soul discovering in humility the truth about human existence, the only source of true happiness of man. The Saint was aware of the need to pray for humility, hence its deliberations ended a sigh: "Oh Jesus, make me humble" , to paraphrase the

3 Cf. L. Balter, Encyklika [Encyclical], [in:] Encyklopedia Katolicka [The Catholic Encyclopedia], Vol. 4, Lublin in 1989, col. 984. 
Teologia duchowości

words of this prayer, you might say, "O Jesus, make me live in the truth about myself".

Human concern about the discovery of the truth in itself is an expression of responsibility not only for himself but also for the shape of societies and states. Roncalli pointed out that the lack of the truth in man moves to the "peoples and nations" making them "poisoning", ie. perverting God's plan: "All the evils which poison men and nations and trouble so many hearts have a single cause and a single source: ignorance of the truth - and at times even more than ignorance, a contempt for truth and a reckless rejection of it. Thus arise all manner of errors, which enter the recesses of men's hearts and the bloodstream of human society as would a plague. These errors turn everything upside down: they menace individuals and society itself. And yet, God gave each of us an intellect capable of attaining natural truth. If we adhere to this truth, we adhere to God Himself, the author of truth, the lawgiver and ruler of our lives"5.

Roncalli expressed his interest in the man and his current issues in the encyclical, which is considered one of the most important documents: Mater et Magistra (1961). Its main theme are social issues. Although the encyclical is primarily entering into the history of catholic social teaching, it is not appropriate to put out of the Christian spirituality of it as well as any other documents of the Magisterium of the Church. Besides the Pope himself, in the first sentence of his allocution formulates its purpose: "Mother and Teacher of all nations - such is the Catholic Church in the mind of her Founder, Jesus Christ; to hold the world in an embrace of love, that men, in every age, should find in her their own completeness in a higher order of living, and their ultimate salvation. She is "the pillar and ground of the truth". To her was entrusted by her holy Founder the twofold task of giving life to her children and of teaching them and guiding them - both as individuals and as nations - with maternal care. Great is their dignity, a dignity which she has always guarded most zealously and held in the highest esteem" 6 .

Referring to the encyclical Rerum Novarum by Leo XIII, Roncalli indicates the basis for the concern of the Church to a man's life was consistent with natural law and consequently corresponding to the gospel counsels ${ }^{7}$.

Ad Petri Cathedram, 1.

Mater et Magistra, Introduction.

Ibidem, 2. 
This expression of concern of the Pope for man refers to the basic principle of spiritual life: Gratia supponit nature et perficit eam (grace presupposes nature and perfects it), reminding that man before he began the realization of the Christian vocation came into being as the creation of what is appropriate to the nature and only later he received supernatural gifts, allowing to achieve the ultimate goal. So if the Pope refers to issues such as economic development, social progress, the common good, the progress of civilization, and even liberalism or free competition it is not in order to write about them, but to show a man in his material and spiritual dimension in their context. The vision of a man who aspire to material well-being with the detriment of spiritual life was expressed by the Pope in one of the speeches mentioned also in Mater et Magistra: "our age is marked by a clear contrast between the immense scientific and technical progress and the fearful human decline shown by "its monstrous masterpiece ... transforming man into a giant of the physical world at the expense of his spirit, which is reduced to that of a pygmy in the supernatural and eternal world"8.

Another opportunity for Roncalli to express the truth about man as the particle of Mystical Body of Christ has become 1500 anniversary of the death of Pope Leo I. On this occasion, in November 1961 Pope promulgated the Encyclical Dei Sapientia Aeterna (God's eternal wisdom). Although the leading theme of the document is the ministry of the Bishop of Rome uniting followers of Christ, it is without a doubt John XXIII was accompanied by theological and anthropological truth that the lack of unity among Christians is the result of original sin and its consequences. This truth calls for the interior conversion as the beginning to unite Christians and the pursuit of human integrated in their mental and physical structure by opening up to the unifying action of the Holy Spirit, so as to make as far as possible the unity of the human being in himself.

It should be noted that Pope indicates also in Aeterna Dei Sapientia one of the objectives of Vatican II: the mission of uniting divided Christians. The council called by Pope John XXIII was actually a breakthrough in in the ecumenical movement initiated in the Protestant circles. Its fruit has become promulgated 21 November 1964, after the death of John XXIII, Decree on Ecumenism Unitatis redintegratio, which recognized "conversion of heart and holiness of life, along with

Ibidem, 4. 
public and private prayer for the unity of Christians [...] for the soul of the whole ecumenical movement".

\section{Simple Spirituality}

Teologia duchowości

The teaching of John XXIII, contained in his encyclicals has not got the feature of systematic doctrine of the Catholic Church. The Pope does not occur in them as a scholastic theologian but rather as a pastor pointing traveled his roads, indicating role models, in which he was finding clear signs in realizing the vocation to holiness.

Such is the second encyclical of John XXIII, announced just one month after the Ad Petri Cathedram, 1 August 1958, on the hundredth anniversary of the death of St. John Mary Vianney, the Curé of Ars, Sacerdotii Nostri Primordia. In the document, the Pope not only outlines the essential characteristics of the spirituality of the Saint form Ars, but also reveals the example of the priestly life "the radiant example of priestly asceticism as well as devotion - especially the Eucharist, and finally, pastoral zeal" ${ }^{10}$.

The simplicity of Roncalli's spirituality, flowing from Sacerdotii Nostri Primordia points to the right of his pastoral teaching method. Christian praxis - asceticism is to culminate in the theoria - the contemplation of God, should become it to fill out the priestly spirituality as the ultimate union of man with God.

An important feature of spirituality of Pope John XXIII was outlined in the teaching coming from the encyclical dedicated to the sacrament of penance Poenitentiam Agere. First of all, it is the awareness of one's personal sin and need for repentance, both external and internal. This truth of human fate expressed in the encyclical accompanied Roncalli in all stages of his spiritual life. It flowed from consideration of the truth about Jesus Christ, whose life is an imperative of the Christian life. In its inherent simplicity of thought Roncalli posted, usually on the occasion of the retreat notes, how much far is he from the life of the one who had called him. Before the sub-diaconate ordination he wrote:

Whenever I contemplate the great mystery of the humble and hidden life that Jesus led the first thirty years I have no words to express my shame. It is obvious that given such a great lesson it shows us all the false not only the judgement of this world, but the judgement and the way of thinking of nearly all the clergy, which are directly opposite of

Sobór Watykański II [The Second Vatican] Dekret o ekumenizmie [Council's Decree on Ecumenism] Unitatis redintegratio, 8. 
what Christ practiced. And I also do not have a clue about it yet. When I scrutinize in my conscience, it seems to me that I find there only a semblance of humility $[\ldots]^{11}$.

In Poenitentiam Agere humility, fundamental to Christian spirituality resonates on the occasion of call for "external repentance". Roncalli recalls the necessity of asceticism, understood in this respect as penance expressed by mortification of the body as atonement for their own and others sins. In this regard, the example is St. Paul the Apostle mystic, but also the one who undertook the mortification of the body, "I keep under my body, and bring it into subjection" (1 Corinthians 9:27) due to adherence to Jesus Christ: "And they that are Christ's have crucified the flesh with the affections and lusts" (Galatians 5:24). In this regard, the Pope appeals and makes himself a close call of St. Augustine: "It is not enough to become a better person and cease to do evil. It should also atone for his sins to God through the pain of repentance, humble groaning, the sacrifice of a contrite heart and alms corresponding with them"12.

Roncalli's call to do penance was the primary source of his personal spiritual experience. Journal of a soul and other writings of the Saint indicate how great emphasis he put on the one hand to various forms of mortification while taking care that they are an expression of genuine humility. Interesting in this regard is the secret of Roncalli's personal cross, as the apostolic delegate in Turkey and Greece. It seems to be the evangelical virtue of obedience tested in relation to the Holy See and relating to difficult situation existing in Turkey. At the date of 1316 October 1956, Roncalli wrote:

the difference between my point of view when it comes to the local situation, certain ways of judging the same things in Rome, it hurts me very much: this is my one true cross. I want to carry it humbly, with all the good will of the satisfaction of my superiors, because I want only this and not anything else. I will always tell the truth, but gently, keeping quiet what I think is personal harm or insult, being ready for sacrifice and becoming a victim. The Lord sees everything and mete out justice to me. First of all, I always want to repay good for evil and learn to put the Gospel above human tricks policy ${ }^{13}$.

Without a doubt, this attitude is an expression of putting spirituality on daily life as an expression of not only the Christian faith but also the confidence that what seems absurd in human reasoning is logic in

\footnotetext{
11 Dziennik duszy [Journal of a soul], 172.

12 Paenitentiam agere, II, 1.

13 Dziennik duszy [Journal of a soul], 254.
} 
Teologia duchowości

God's economy, which led Roncalli from Turkey via Paris and Venice to the See of Peter.

A significant source of spirituality of Roncalli's simplicity is Franciscan spirituality. In 1896 as a seminarian he entered the Third Order of St. Francis of Assisi ${ }^{14}$ deciding to support his life by three, as St. John Paul II called, pillars: fidelity to Christ and to the Gospel lived out in love and poverty, filial devotion to the Mother of God and fidelity to the Church $^{15}$.

As a spiritual son of St. Francis, Roncalli promoted spirituality of supernatural peace and reconciliation dialogue between people ${ }^{16}$. Among others on the basis of this spirituality grew the last encyclical of John XXIII, which is a kind of the culmination of his pontificate, announced on 11 April 1963, less than two months before his death. It is a response to the so-called "Cuban missile crisis" in which arose the conflict between the two world powers: the United States and the Soviet Union and takes the side of the man threatened by it.

Once again, the Pope recalled the basic conclusions flowing from the basic principles of the natural law: the right and duty to maintain their own life, the right to respect and obligation of decent life, the right and duty to seek the truth, the right to worship, the right to free choice of state; the right and obligation to maintain and educate their children, the right and duty to gainful employment, the right to economic activity, the right to private property, the right to association, the right to emigration and immigration, the right to participate in public life ${ }^{17}$.

According to Pope's thought observance of them is needed in the development of appropriate human nature. But development has often precedes the spiritual needs of man, marginalizing them and by this kind of "degrading" hierarchy of human constitution and human needs. Hence the papal demand for synchronizing faith and life:

This raises the legitimate question of why this is happening, since to determine whether this development contributed most and continue to contribute to those who consider themselves to be Christians, and

14 Cf. Jan XXIII, Refleksje nad regutami franciszkańskimi [Reflections on the Franciscan rules], Warszawa - Kraków 2010, p. 37.

15 Cf. Jan Paweł II, Społeczeństwo potrzebuje dziś obecności świętego Franciszka. Do uczestników kapituty generalnej Zakonu Braci Mniejszych [Society today needs the presence of St. Francis. To the participants in the General Chapter of the Order of Friars Minor], "L’Osservatore Romano" (PL), 8 (1985), p. 9.

16 Cf. S. B. Brzuszek et al., (eds.), Btogostawiony Jan XXIII, papież, wierny naśladowca św. Franciszka z Asyżu [Blessed John XXIII, Pope, the loyal follower of St. Francis of Assisi], Warsaw - Łódz - Zakroczym 2011. 
indeed adapt, at least in part, their lives to the principles of the Gospel. We believe that this state of affairs comes from the fact that people do not attune their beeds with their faith. They should come to this renewal in his internal unity so as their action be guided by both the light of faith and the power of love ${ }^{18}$.

\section{Mystical spirituality}

According to Sacerdotii Nostri Primordia, the aforementioned Christian praxis leading to theoria draws from the Eucharist. Pope referring to the life of St. John Mary Vianney writes: "Almost beyond belief with what fervor of piety he was referring to Christ present in the Blessed Sacrament. "There is - he used to say - he who so loved us; why do not we love Him"? He actually surrounded the Sacrament of the Altar with tender love, and his heart was tearing towards the tabernacle a top gust, which he could not resist. He taught his parishioners a way of prayer:

You do not need many words to pray well. By faith we believe that there, in the Saint Tabernacle is present the good Lord; open the heart for him; rejoice that he let us be really close to him; it is the best way of prayer. "Nothing more did he do to arise reverence and love of the faithful for Christ hidden in the Sacrament of the Eucharist, and to persuade them to nourishing themselves with divine food. His personal example was ahead of everyone". According to witnesses, to convince someone it was enough to look at him as he was celebrating the Mass or even just as he knelt when he passed in front of the tabernacle ${ }^{19}$.

This figure of spirituality of the Saint from Ars also characterized Roncalli. The study on his thought allows to capture his personal mystical experience. Typically, it is understood as psychosomatic, extraordinary knowledge of God, which was also shared by St. Teresa of Jesus, St. Faustina Kowalska or St. Pio from Pietralcina. However, this is only one of the forms of Christian mysticism. In fact every stand in faith to the Triune God creates mystical aspect of life. According to Fr. J. Gogola mysticism consists of four types of experiences: mystical force, as the development of the grace of baptism, which includes the life of the Trinity and allows the supernatural communion with persons of the Trinity; mystical experience in which God reveals himself in man without the mediation of concepts or images of the human being passively subjected to the action of the Holy Spirit; simple intellectual

$\overline{18 \quad \text { Ibidem, } 152 .}$

19 Sacerdotii Nostri Primordia, 4. 
Teologia duchowości

vision of God for loving knowledge of Him or "infused contemplation" and finally the mystic in the full sense of it that is infused and loving knowledge of God through which man experiences the mystery of Christ $^{20}$.

Writing about Eucharistic spirituality of John Mary Vianney and his mystical experience of the Eucharistic God, Roncalli is seen not only as a person showing the way for others, but also as one who followed it.

Journal of a soul, on the date of 22 April 1903, while still a seminarian preparing for ordination he wrote: "having humbled, I'll be trying to be in the presence of Jesus, shining in the rays of his Sacred Heart, under the Eucharistic species"21. Without a doubt he indicates here the value of adoration of the Blessed Sacrament. It was a source of spiritual life of the Saint of Ars and created the foundation for a future pope's spirituality.

This "relationship" with the living God in the form of bread was not only the source of his spiritual life, but also the engine of his apostolic action. Church determines this direction of the priest spirituality, indicating that contemplation should lead to the apostolate which also should lead to the personal unification with God: "The Eucharist gives us unmatched energy that is needed to fulfill our responsibilities, maintain patience, act against everyone and everything - of course, not in combat, but by acquiring and bottling the spirit of holiness"22.

St. John Mary Vianney shown by St. John XXIII as a mystic benefiting from the Eucharistic life suited his personal vision of a Christian as "a man of the Eucharist":

The Eucharist in nature is the sacrament of reconciliation and peace. Everyone who boasts the name of Christian, if they take it in the spirit of love and holiness, unite intimately with God and with each other into strong union, which points the community, the congregation, the body. And there's nothing hostile to those who eat this bread, but hostility, anger, envy, which destroy the unity of brotherhood ${ }^{23}$.

Spirituality of Roncalli was mariological. It is not difficult to find it in his teaching referring to Mary. The Pope dedicated his first encyclical Grata Recordatio (1959) or in the same rank Rosary on equitable peace between nations the document from 1961. In this way, he inscribed in

20 Cf. J. Gogola, Teologia komunii z Bogiem [Theology of communion with God], Kraków 2001, p. 251-270.

Dziennik duszy [Journal of a soul], 160.

Jan XXIII, Pope paternal tenderness [The choice of thoughts]. Ojcowska czułość papieża. Wybór myśli, Częstochowa 2000, p. 30.

Jan XXIII, Myśli najprostsze [The simplest thoughts], Kraków 2000, p. 8. 
the tradition of the Church, calling by popes to pray the rosary in the month of October in various intentions of the Church.

In the message of John XXIII the rosary is a contemplative prayer, introducing into the depths of the spiritual life by meditating on the mysteries of the Gospel. The Pope writes: "First of all clean, bright and quick recollection of every secret, it is these truths of faith that tell us about the redemptive mission of Jesus. When we consider them, we are in the internal communication of thoughts and feelings with the teachings and life of Jesus, the Son of God and Son of Mary, who lived on the earth, to redeem, to teach to sanctify - in the silence of his hidden life filled with prayer and work - in the sufferings of His holy Passion - in the triumph of the Resurrection, as well as in the glory of heaven, where he sits at the right hand of the Father, always keeping in memory care and enlivened by the Holy Spirit, the Church founded by Jesus and rolling on its path through the centuries"24.

The life and ministry of A. G. Roncalli as a priest and bishop reveals the truth proper to the theology of Christian spirituality about its absolutely pneumatological dimension. It unites the personal life of man, with all that it creates in him the ontological unity. In the case of a cleric it involves the unification of who you are with what you proclaim while opening up the life and ministry for the penetration of the Holy Spirit. It does not make man - the priest, the bishop a saint in the starting point but rather in the experience of sin and weakness introduces the path of conversion and change of life toward the ultimate union with God in Jesus Christ. Hence Roncalli's personal spiritual experience and his apostolic ministry formed the ontological unity.

Key words: John XXIII, folk spirituality, simple spirituality, mystical spirituality

\section{Bibliography:}

1. Balter L., Encyklika [Encyclical], [in: ]Encyklopedia Katolicka [The Catholic Encyclopedia], Vol. 4, Lublin 1989.

2. Brzuszek S. B. et al., (Eds.), Błogostawiony Jan XXIII, papież, wierny naśladowca św. Franciszka z Asyżu [Blessed John XXIII, Pope, the loyal follower of St. Francis of Assisi], Warsaw - Łódz - Zakroczym 2011.

3. Capovilla L. F., La spiritualità di Giovanni XXIII e le Sue Radici, in http:// www.papagiovanni.com/sito/pensiero/articoli-e-studi.html [access date:17 November 2015].

4. Giovanni XXIII, Ad Petri Cathedram.

$24 \quad$ Apostolic Letter Il religio so Convegno, Mystical contemplation, 4. 
5. Giovanni XXIII, Apostolic Letter Il religio so Convegno, Mystical contemplation.

6. Giovanni XXIII, Lettere ai famigliari, Roma 1968.

7. Giovanni XXIII, Mater et Magistra.

8. Giovanni XXIII, Pacem in terris.

9. Giovanni XXIII, Paenitentiam agere.

10. Giovanni XXIII, Sacerdotii Nostri Primordia.

11. Gogola J., Teologia komunii z Bogiem [Theology of communion with God], Kraków 2001.

12. Jan Paweł II, Społeczeństwo potrzebuje dziś obecności świętego Franciszka. Do uczestników kapituty generalnej Zakonu Braci Mniejszych [Society today needs the presence of St. Francis. To the participants in the General Chapter of the Order of Friars Minor], "L'Osservatore Romano" (PL), 8 (1985).

13. Jan XXIII, Dziennik duszy [Journal of a soul].

14. Jan XXIII, Myśli najprostsze [The simplest thoughts], Kraków 2000.

15. Jan XXIII, Pope paternal tenderness [The choice of thoughts]. Ojcowska czułość papieża. Wybór myśli, Częstochowa 2000.

16. Jan XXIII, Refleksje nad regutami franciszkanskimi [Reflections on the Franciscan rules], Warszawa - Kraków 2010.

17. Roncalli A. G., Il lupo, l'orso, l'agnello. Epistolario bulgaro con don K. Raev e mons. D. Theelen, Cinisello 2013.

18. Roncalli A. G., Lettere dall'Oriente e altre inedite, Panzano in Chianti 2010.

19. Roncalli A. G., Lettere del pontificato, Cinisello 2008.

20. Roncalli A. G., Lettere di fede e amicizia (1925-1963), Roma 2013.

21. Roncalli A. G., Questa Chiesa che tanto amo: lettere ai vescovi di Bergamo, Cinisello 2002.

22. Sobór Watykański II [The Second Vatican] Dekret o ekumenizmie [Council's Decree on Ecumenism] Unitatis redintegratio. 